Supporting Information

\title{
A Microbial Platform Based on Conducting Polymers for Evaluating Metabolic Activity
}

Maki Saito, Kengo Ishiki, Dung Q. Nguyen, and Hiroshi Shiigi*

aDepartment of Applied Chemistry, Osaka Prefecture University, 1-2 Gakuen, Naka, Sakai, Osaka 599-8570, Japan

*Corresponding author: shii@chem.osakafu-u.ac.jp

Table of contents

Figures $\mathrm{S} 1$ to $\mathrm{S6}$

Tables $S_{1}$ and $S_{2}$ 

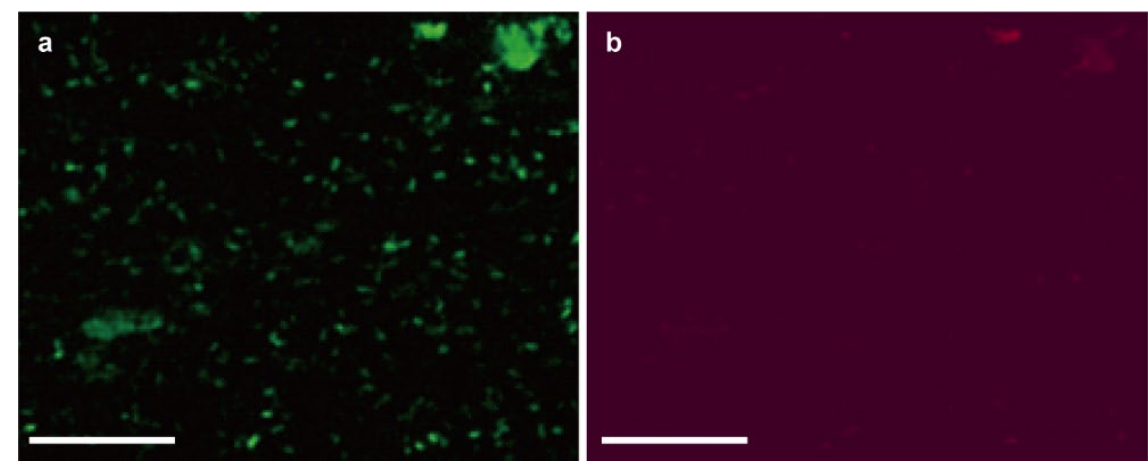

Figure S1. Fluorescent images of the as prepared A. xylinus-doped PEDOT film stained using the LIVE/DEAD BacLight Bacterial Viability Kit, (a) excitation with blue light (465-495 nm) and (b) green light (525-540 nm). Living cells stained with Sytog were observed as green spots and dead cells were observed as red spots with propidium iodide. Scale bars are $50 \mu \mathrm{m}$. 

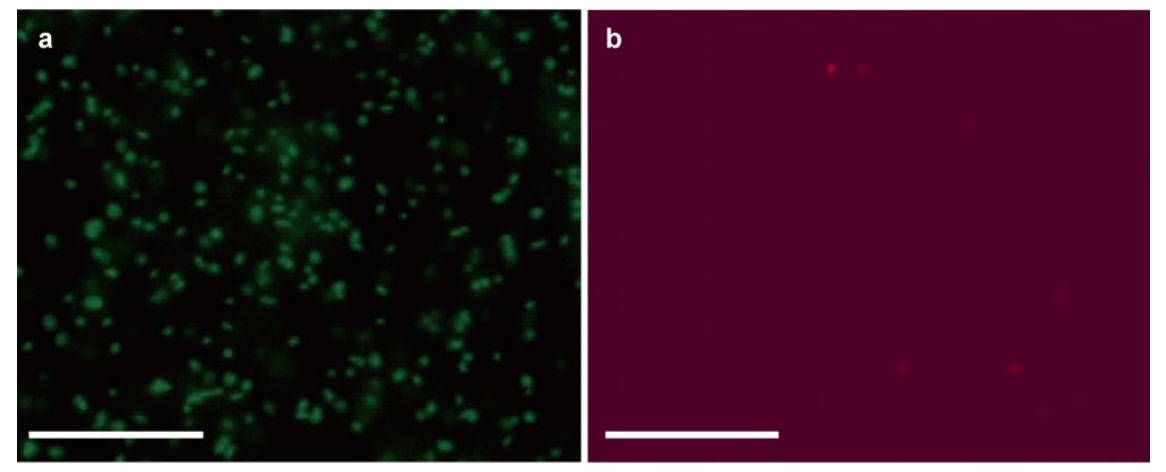

Figure S2. Fluorescent images of the as prepared E. coli-doped PPy film stained using the LIVE/DEAD BacLight Bacterial Viability Kit, (a) excitation with blue light $(465-495 \mathrm{~nm})$ and (b) green light (525-540 $\mathrm{nm})$. Scale bars are $50 \mu \mathrm{m}$. 


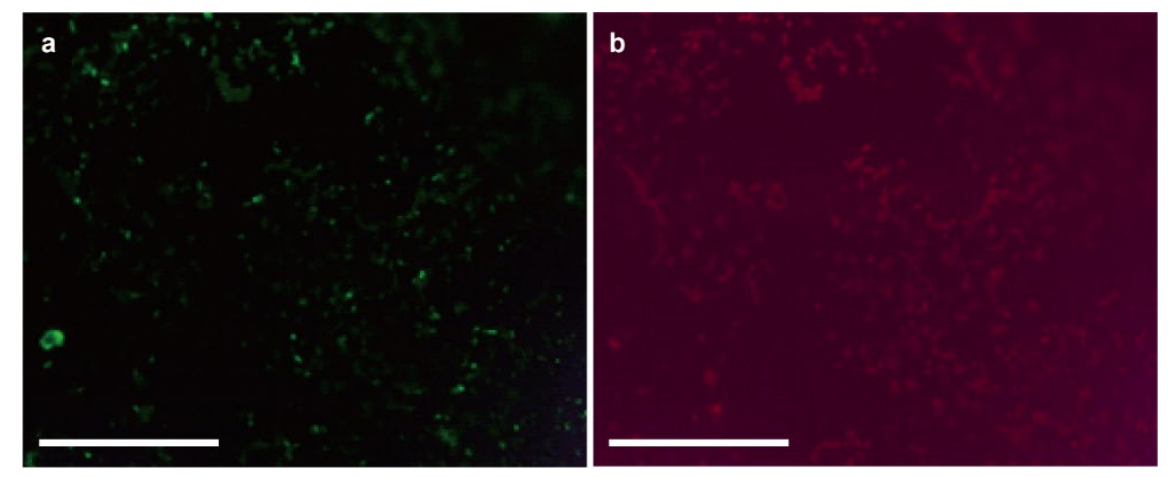

Figure S3. Fluorescent images of the as prepared E. coli-doped PPy film after incubation for $48 \mathrm{~h}$. They were stained using the LIVE/DEAD BacLight Bacterial Viability Kit. Scale bars are $100 \mu \mathrm{m}$. 

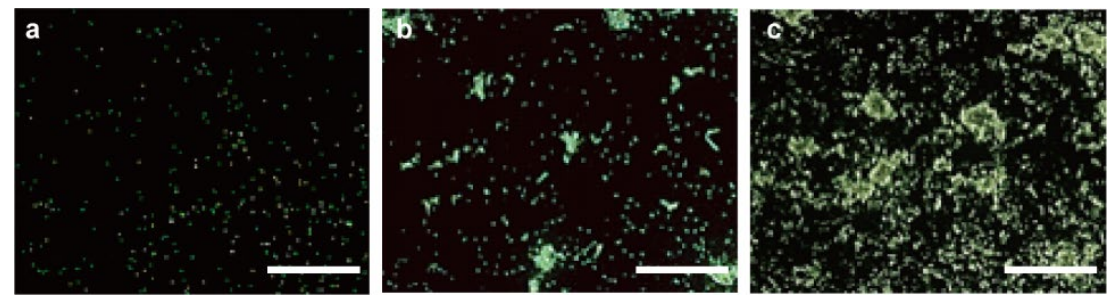

Figure S4. Dark-field images of the E. coli-doped PPy film incubated in liquid NB medium for (a) o h, (b) 9 h, and (c) $18 \mathrm{~h}$ under anaerobic conditions. Scale bars are $100 \mu \mathrm{m}$. 

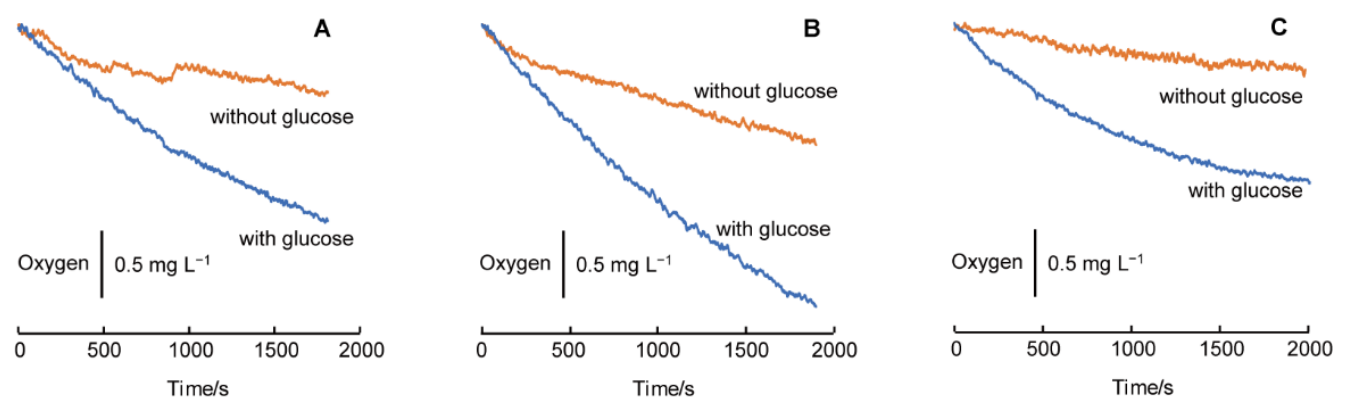

Figure $\mathrm{S}_{5}$. Dissolved oxygen concentration in a stirred bacterial suspension ( $\left.8 \mathrm{~mL}\right)$ with and without $20 \mathrm{mM}$ glucose. (A) E. coli ( $4.2 \times 10^{5}$ cells), (B) S. enterica $\left(5.4 \times 10^{5}\right.$ cells), (C) P. aeruginosa $\left(2.1 \times 10^{5}\right.$ cells). 

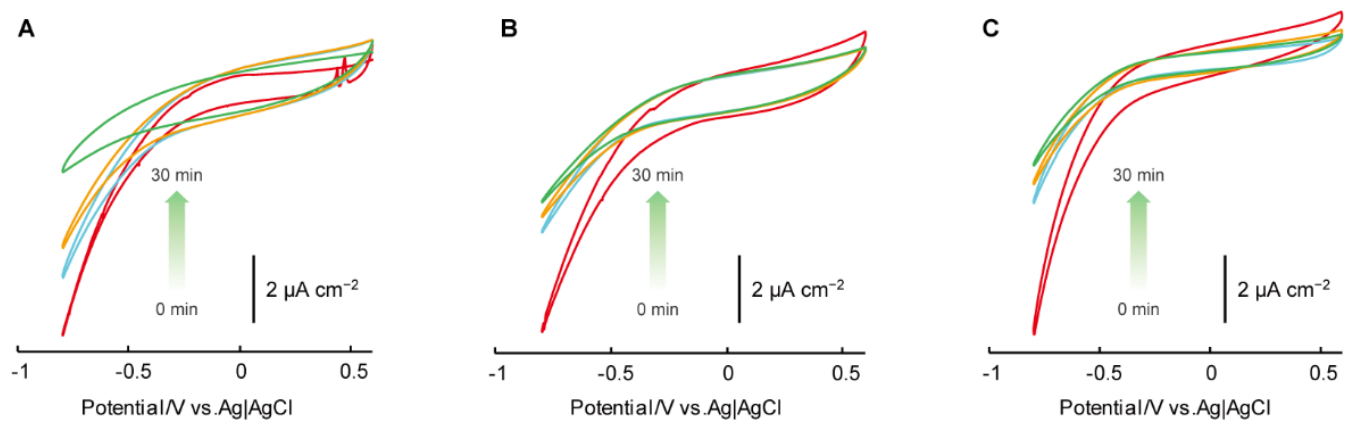

Figure S6. Aerobic Cyclic voltammograms of (A) E. coli $\left(1.6 \times 10^{5}\right.$ cells)-, (B) S. enterica $\left(1.3 \times 10^{5}\right.$ cells)-, (C) P. aeruginosa $\left(1.5 \times 10^{5}\right.$ cells $)$-immobilized PPy films recorded in the thin-layer electrolysis cell containing $20 \mathrm{mM}$ glucose during incubation for $30 \mathrm{~min}$. Polymerization times of $100 \mathrm{~s}$ were used, respectively. 
Table S1. Oxygen consumption per single cell obtained by electrochemical measurements

\begin{tabular}{cccc}
\hline Bacteria & $\begin{array}{c}\text { Number of cells } \\
/ \text { cells }\end{array}$ & $\begin{array}{c}\text { Electric charge } \\
/ C\end{array}$ & $\begin{array}{c}\text { Respiratory } \\
\text { activity }^{\mathrm{c}} \\
\text { mol min }^{-1} \text { cell }^{-1}\end{array}$ \\
E. coli & $2.0 \times 10^{5}$ & $2.0 \times 10^{-5}$ & $1.8 \times 10^{-17}$ \\
& $1.6 \times 10^{5}$ & $1.3 \times 10^{-5}$ & $1.4 \times 10^{-17}$ \\
S. enterica & $1.8 \times 10^{5}$ & $1.5 \times 10^{-5}$ & $1.5 \times 10^{-17}$ \\
& $1.3 \times 10^{5}$ & $1.2 \times 10^{-5}$ & $1.6 \times 10^{-17}$ \\
P. aeruginosa & $2.0 \times 10^{5}$ & $1.5 \times 10^{-5}$ & $1.3 \times 10^{-17}$ \\
& $1.5 \times 10^{5}$ & $1.3 \times 10^{-5}$ & $1.5 \times 10^{-17}$ \\
\hline
\end{tabular}

aNumber of cells immobilized on the PPy film. bThe difference in the electric charge was obtained with and without the addition of glucose. 'Respiratory activity was calculated by dividing the moles of consumed oxygen by the cell number. 
Table S2. Oxygen consumption per single cell obtained by optical sensor

\begin{tabular}{|c|c|c|c|c|}
\hline \multirow{2}{*}{ Bacteria } & \multirow{2}{*}{$\begin{array}{l}\text { Number of cells }{ }^{\mathrm{a}} \\
\text { /cells }\end{array}$} & \multirow{2}{*}{$\begin{array}{l}\text { Consumed oxygen } \\
/ \mathrm{mg} \mathrm{L}^{-1} \mathrm{~min}^{-1}\end{array}$} & \multicolumn{2}{|c|}{ Respiratory activity } \\
\hline & & & $/ \mathrm{mol} \mathrm{min}^{-1}$ cell $^{-1}$ & S.D. $/ \%$ \\
\hline \multirow{3}{*}{ E. coli } & $2.4 \times 10^{5}$ & $1.9 \times 10^{-5}$ & $2.0 \times 10^{-17}$ & \\
\hline & $4.2 \times 10^{5}$ & $3.2 \times 10^{-5}$ & $1.9 \times 10^{-17}$ & 12 \\
\hline & $6.9 \times 10^{5}$ & $6.6 \times 10^{-5}$ & $2.4 \times 10^{-17}$ & \\
\hline \multirow{3}{*}{ S. enterica } & $6.7 \times 10^{5}$ & $6.7 \times 10^{-5}$ & $2.5 \times 10^{-17}$ & \\
\hline & $6.0 \times 10^{5}$ & $5.5 \times 10^{-5}$ & $2.3 \times 10^{-17}$ & 17 \\
\hline & $5.4 \times 10^{5}$ & $3.8 \times 10^{-5}$ & $1.8 \times 10^{-17}$ & \\
\hline \multirow{3}{*}{ P. aeruginosa } & $2.1 \times 10^{5}$ & $1.3 \times 10^{-5}$ & $1.5 \times 10^{-17}$ & \\
\hline & $4.5 \times 10^{5}$ & $1.9 \times 10^{-5}$ & $1.0 \times 10^{-17}$ & 47 \\
\hline & $8.3 \times 10^{5}$ & $8.7 \times 10^{-5}$ & $2.6 \times 10^{-17}$ & \\
\hline
\end{tabular}

${ }^{a}$ Number of cells in an eight $\mathrm{mL}$ of bacterial suspension. ${ }^{b}$ Amount of consumed oxygen. cRespiratory activity was calculated by dividing the moles of consumed oxygen by the cell number. 